\title{
真空中での宇宙 GHTA 溶接法によるアルミニウム合金の突合せ溶接*1 Butt Welding of Aluminum Alloy by Space GHTA Welding Process in Vacuum
}

\author{
吹田 義 $-* 2$. 新 池修 平*3. 江 國 友 英*3.寺 嶋 昇 ${ }^{* 2}$ \\ Yoshikazu Suita, Shuhei Shinike, Tomohide Ekuni, Noboru Terajima, \\ 佃芳 行*2.今 川吉 郎*4 \\ Yoshiyuki TsukUdA and Kichiro Imagawa
}

Key Words : ISS, Space Welding, Space GHTA Welding, Aluminum Alloys, Butt Welding, Filler Wire, Vacuum

\begin{abstract}
Aluminum alloys have been widely used in the constructing various space structures including the International Space Station (ISS) and launch vehicles. For space application, welding experiments of an aluminum alloy were conducted by the GHTA (Gas Hollow Tungsten Arc) welding processes using a filler wire feeder in vacuum. We investigated the melting phenomena of a base metal and a filler wire, bead formation phenomena and effects of wire feeding speed on melting characteristics. The melting phenomenon of melt-run welding with a filler wire was basically the same as that of without a filler wire. It was clarified that the effects of wire feeding speed on bead sizes and configurations. Furthermore the butt welding joints were welded by the optimum wire feeding speed and the tensile strengths of those joints were evaluated. The mean value of tensile strengths of butt welding joints that were made using d.c.-pulsed GHTA welding with filler wire in vacuum was almost same value as that was welded by GTA (Gas Tungsten Arc) welding in air.
\end{abstract}

\section{1. 緒論}

2003 年 2 月 1 日, 乗員 7 名全員が死亡するシャトル・コ ロンビアの空中分解事故が起きた. 事故調査委員会は, 打 ち上げ直後に外部燃料タンクから剝がれ落ちた断熱材が左 翼前縁部耐熱パネルを損傷させ , 大気圏再突入の際に高温 ガスが損傷部から左翼内部に侵入して空中分解したと結論 づけた．事故発生後, NASA は原因が解明されるまでシャ トルの打ち上げを凍結したために国際宇宙ステーション ISS (International Space Station) の完成は 2010 年頃になる 予定である. ISS の運用期間は種々の理由から延長される 可能性もある . 運用期間の長期化によってデブリ衝突や搭 載機器の修理, 高機能化の改造要求がでることも予想され る . また, 月面基地建設や太陽発電衛星などの宇宙構造物 の建造を考えると，今後の宇宙開発では宇宙空間での溶接 技術や加工技術の適用が期待 ${ }^{11}$ される。

旧ソ連邦は宇宙溶接技術の必要性を早くから認識し，1960 年頃から電子ビーム溶接2)を中心に研究開発を開始した 1984 年にはサリュート 7 号の船外で電子ビーム溶接実験に 成功したが , 実験結果の詳細を明らかにしていない . 米国 でも電子ビーム溶接 31 や Nd-YAGレーザ溶接 ${ }^{4)}$ の研究が行 われた .しかし, 電子ビーム溶接には安全性の問題 , レーザ

\footnotetext{
*1 C 2004 日本航空宇宙学会

平成 16 年 5 月 12 日原稿受理

*2 高松工業高等専門学校制御情報工学科

*3 高松工業高等専門学校専攻科

*4 独立行政法人宇宙航空研究開発機構
}

溶接には低発振効率, 大型・重量などの問題があつた . 1989 年にNASA は宇宙航空, 溶接関連の技術者, 研究者を集め て宇宙溶接研究集会5) を開催し，宇宙溶接技術の必要性と 可能性を再確認した . 1992 年には ISS 修理などに溶接技術 が適用できるのを確認するために，旧ソ連邦が開発した電 子ビーム溶接装置をシャトルに搭載してカーゴベイで溶接 実験をする計画を発表した．しかし，実験実施の半年前の 1997 年 3 月に , スケジュールや宇宙飛行士の安全性確保な どに問題が発生したために実験を無期延期6)にした．光の ため, 現時点では NASA の宇宙溶接技術開発は行き詰まり 状態にある .

このような状況下で, 著者らは 1992 年に宇宙空間で安全 に適用できる溶接技術として , 中空タングステン電極を採 用した宇宙 GHTA (Gas Hollow Tungsten Arc) 溶接技 術を発表7 9) した．关して，光の研究開発を実施して次節 で述べるように宇宙 GHTA 溶接技術を宇宙適用するため の要素技術を確立した . 谷の結果, ISS 搭載機器に電磁ノ イズ障害を与えることなく，フィラーワイヤ (溶加材) を 溶融池に供給して充分な継手強度を有するアルミニウム合 金の突合せ溶接継手を製作できる溶接技術を確立できたの で報告する．

\section{2. 宇宙 GHTA 溶接技術の開発経緯と 課題}

真空中で中実タングステン電極を使用する従来の GTA (Gas Tungsten Arc) 溶接を行うと，アーク放電が拡がる 現象やアークが Ar ガス流出孔に集中して銅製トーチ部品 
を損傷させ，アークが消失する現象 ${ }^{8,9)}$ を確認した . 著者 らは, 弚の現象に注目して中空タングステン電極を採用し， 兴の先端からのみ不活性ガスを流出させる宇宙 GHTA 溶 接法を考案した . 乥して, 1998 年には航空機の放物飛行で 得られる模擬宇宙環境下でステンレス鋼の宇宙 GHTA 溶 接実験 ${ }^{10)}$ に成功し，宇宙空間で利用できる可能性を示した

ISS 周辺の宇宙空間でアルミニウム合金製の宇宙構造物 の建造，修理に宇宙 GHTA 溶接を適用するためには，次 の課題が残されていた .

(1) 高周波高電圧アーク起動時の電磁ノイズ障害対策

(2) 溶接中の溶融池表面の酸化膜除去技術の確立

(3) フィラーワイヤを供給する溶接技術の確立

（1）については，直流高電圧アーク起動方式のアーク起動 を実現 ${ }^{11)} し て$ 解決した . (2) については, 直流パルス溶接 電源を採用してアーク衝撃圧力によって溶融池表面の酸化 膜を機械的に粉砕除去する方法 ${ }^{12)}$ て解決した . 本論文では， (3) のフィラーワイヤを溶融池に供給する溶接技術によっ て充分な継手強度を有する突合せ溶接継手か得られること を実証している，弚の結果，宇宙空間で宇宙構造物の建造 や修理に宇宙 GHTA 溶接を適用するための要素技術を確 立することができた．今後に残された課題は，微小重力・ 真空の模擬宇宙環境でのアルミニウム合金溶接の実証実験 である .

\section{3. 実 験 方 法}

3.1 実験装置 第 1 図に真空中での溶接実験に使用し た真空環境 GHTA 溶接実験装置を示す.内径 $0.5 \mathrm{~m}$, 高 さ $0.5 \mathrm{~m}$ のステンレス鋼製真空チャンバ内を油回転ポンプ $\left(0.26 \mathrm{~m}^{3} / \mathrm{s}\right)$ と油拡散ポンプ $\left(0.35 \mathrm{~Pa} \cdot \mathrm{m}^{3} / \mathrm{s}\right)$ で排気した .

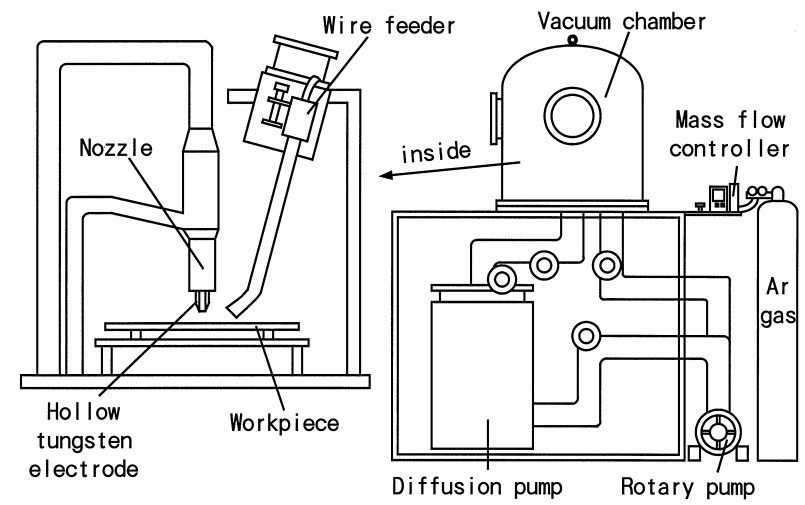

第1図 真空環境 GHTA 溶接実験装置
チャンバ内部には中空タングステン電極を採用した水冷方 式 GHTA 溶接卜ーチと直線移動する走行台車を内蔵して いる.溶接中の溶融池にフィラーワイヤを供給するために 真空モータ駆動の小型ワイヤ供給装置もチャンバ内部に設 置した．アーク作動ガスである Ar ガス流量を制御するた めにマスフローコントローラを使用した . 溶接機は高周波 アーク起動装置付きインバータ交直両用 GTA 溶接機を使 用した . 溶接機の電源モードは直流パルス電源, 極性は電 極マイナス極性 (DCEN) として GHTA 溶接実験を行っ た . 放電および溶融状況をビデオカメラて録画した .

3.2 供試材及び実験手順 宇宙輸送システムや宇宙ス テーションなどの宇宙構造物は, 溶接性を考慮してアルミニ ウム合金 A2219-T6 が使用される．しかし，A2219-T6の 薄板が入手困難なことから，溶接性は多少劣るが A 2014-T6 を供試材として採用した.第 1 表 (a) に供試材の化学成分を， 第 1 表 (b) に機械的性質を示す. 供試材寸法は板厚 $4 \mathrm{~mm}$, 板幅 $75 \mathrm{~mm}$, 長さ $150 \mathrm{~mm}$ とし, 表面状態は受け入れ状態 で脱脂処理のみを行った . フィラーワイヤには A4043-WY (直径 $1 \mathrm{~mm}$ ) を使用した.第 2 図に GHTA 溶接卜ーチの詳 細を示した .中空タングステン電極は外径 $D=4 \mathrm{~mm}$ ，内 径 $d=1.8 \mathrm{~mm}$ の $2 \%$ 酸化ランタン $\left(\mathrm{La}_{2} \mathrm{O}_{3}\right)$ 入りタングス テン電極で, 先端を電極研磨機で頂角 $60^{\circ}$ に成形し, 電極 高さ (アーク長) $H_{\mathrm{E}}=3 \mathrm{~mm}$, ノズル高さ $H_{\mathrm{N}}=15 \mathrm{~mm}$ とした 、溶接電流条件はパルス電流 $I_{\mathrm{P}}=200 \mathrm{~A}$, ベース 電流 $I_{\mathrm{B}}=40 \mathrm{~A}$ ，パルス幅 $W_{\mathrm{P}}=17.5 \%$ ，パルス周波数 $F_{\mathrm{P}}=3 \mathrm{~Hz}$ とし, Ar ガス流量は $Q_{\mathrm{Ar}}=1.67 \mathrm{ml} / \mathrm{s}$, 溶接 前の初期容器内圧力は $0.4 \mathrm{~Pa} の 一$ 定值とした . 溶接速度 は $v=5.8 \sim 6.6 \mathrm{~mm} / \mathrm{s}$, フィラーワイヤ供給速度は $V_{\mathrm{W}}=$ 26 $55 \mathrm{~mm} / \mathrm{s}$ の間て変化させた . 光して, フィラーワイヤ 供給溶接時の母材, ワイヤの溶融蟣構, フィラーワイヤ供

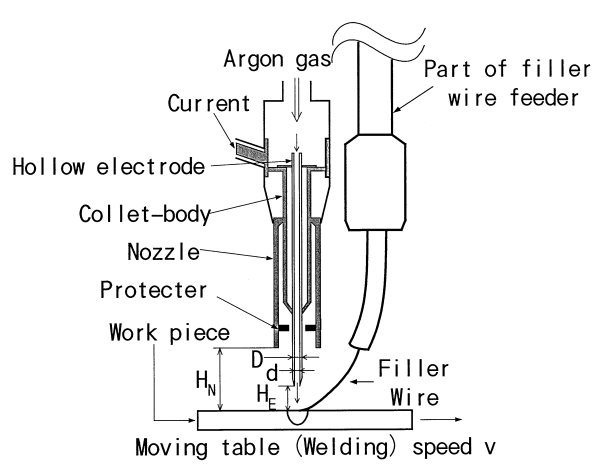

第 2 図 GHTA 溶接卜ーチの詳細

第 1 表 アルミニウム合金 A2014-T6 の化学成分と機械的性質 a) Chemical compositions of aluminum alloy used (mass\%)

\begin{tabular}{ccccccccccc}
\hline & $\mathrm{Si}$ & $\mathrm{Fe}$ & $\mathrm{Cu}$ & $\mathrm{Mn}$ & $\mathrm{Mg}$ & $\mathrm{Cr}$ & $\mathrm{Zn}$ & $\mathrm{Zr}+\mathrm{Ti}$ & $\mathrm{Ti}$ & $\mathrm{Al}$ \\
\hline $\mathrm{A} 2014-\mathrm{T} 6$ & 1.06 & 0.37 & 4.66 & 0.85 & 0.69 & 0.05 & 0.07 & 0.04 & 0.03 & $\mathrm{RE}$ \\
\hline
\end{tabular}

b) Mechanical properties

\begin{tabular}{ccccc}
\hline & $\begin{array}{c}0.2 \% \text { proof stress } \\
(\mathrm{MPa})\end{array}$ & $\begin{array}{c}\text { Tensile strength } \\
(\mathrm{MPa})\end{array}$ & $\begin{array}{c}\text { Elongation } \\
(\%)\end{array}$ & $\begin{array}{c}\text { Vickers hardness } \\
(9.8 \mathrm{~N})\end{array}$ \\
\hline A2014-T6 & 441 & 478 & 10.1 & 170.2 \\
\hline
\end{tabular}




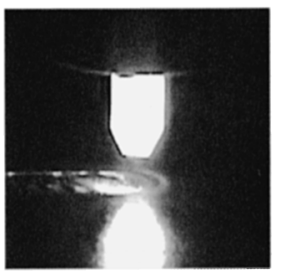

(1)

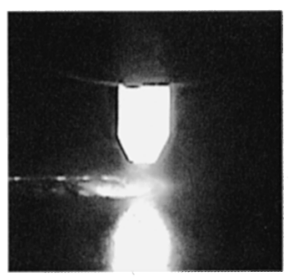

(2)

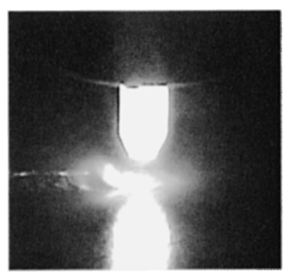

(3)

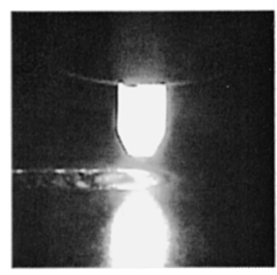

(4)

第 3 図 メルトラン溶接における放電・溶融状況

給速度がビード高さ，ビード幅に及ぼす影響について調査 した，最後に，I型開先突合せ溶接継手を製作して，溶接 継手の硬度分布，引張強さを調査した。

\section{4. 実験結果と考察}

\section{1 フィラーワイヤ及び母材の溶融とビード 形成機構}

4.1.1 メルトラン溶接における母材の溶融とビード形成 機構 溶接電流条件と $\mathrm{Ar}$ ガス流量を 3.2 節で示した值に 設定して, 溶接速度 $v=6.6 \mathrm{~mm} / \mathrm{s}$ でフィラーワイヤを供 給しないで母材のみを溶融させるメルトラン溶接を行った 第 3 図(1)〜 (4)は, 兴の時の母材の溶融とビード形成状況の 時間的変化である . また，第 3 図(1)〜 (4)の溶接状況にある 時の溶接電流，電圧を第 4 図中に同じ番号(1)〜(4)で示した . ビデオ観察結果から母材の溶融とビード形成機構を記述す る. 第 4 図中(1)の電流の小さいベース電流時はエネルギ不 足のためにアークは第 3 図(1)ように母材を溶融させるこ とができない，しかし，第4図中(2)，(3)のように大電流のパ ルス電流になると第 3 図(2)，(3)のようにアークが母材を溶 融させ , アークの衝撃圧力によって溶融池を下方に掘下げ， また同時に溶融金属を凸状に変形させて後方に吹き飛ばす ビード形成状況か確認できた . このときのアーク衝撃圧力， 溶融金属の変形によって溶融金属表面の酸化膜 $\mathrm{Al}_{2} \mathrm{O}_{3}$ (膜 厚は $70 \sim 200 \mathrm{~nm}$ 程度) が機械的に粉砕除去される. 乥し て, 再び第 4 図中(4)の小電流のベース電流になったときは， 第 3 図(4)のようにパルス電流時の溶融金属が㠜固するビー ド形成機構か観察できた .このように，直流パルス電源を 使用した真空中での GHTA 溶接では, ある限られた溶接 条件範囲であるがアルミニウム合金溶融池表面の酸化膜を 機械的に粉砕除去できる現象 ${ }^{12)}$ を確認できた .この酸化膜 除去機構は, 大気中の交流 GTA 溶接でみられるクリーニ ング作用とは全く異なる機構である.酸化膜除去が可能に なった結果，母材溶融金属とフィラーワイヤ溶融金属間の ぬれ性か改善され，融合不良などの溶接欠陥を発生するこ となく次節で述べるフィラーワイヤを供給する溶接が可能 になった．なお，粉砕された酸化膜は溶融金属内に混入し たり，溶接金属表面に残留している。

4.1.2 フィラーワイヤ供給時の母材の溶融とビード形成 機構 第 5 図はフィラーワイヤを供給しながら溶接を行っ た場合の母材の溶融とビード形成状況の時間的変化である . 母材の溶融についてはフィラーワイヤを供給しない第 3 図
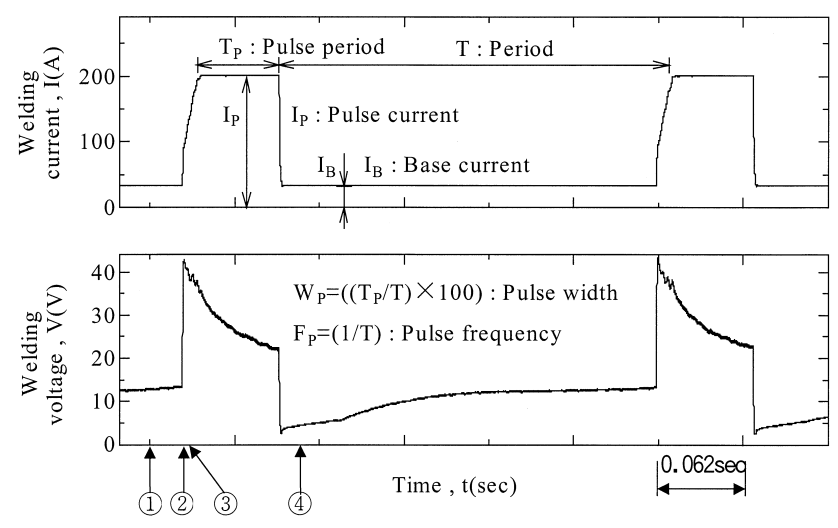

第 4 図 溶接電流, 電圧波形

のメルトラン溶接の場合とほぼ同じ溶融状況であった . 一 方, フィラーワイヤの溶融は, 第 5 図(1)のよにベース電 流時に溶融をはじめ, 第 5 図(2)のパルス電流時には母材に 溶融池が形成されるとともに溶融したフィラーワイヤの溶 滴が溶融池に移行する樣子が観察できた。第 5 図(3)では， フィラーワイヤと母材が溶融した溶融金属が後方に吹き飛 ばされていることがわかる . 第 5 図(4)は次の周期のベース 電流時であり，再びフィラーワイヤの溶融開始が確認でき る.フィラーワイヤを供給することで容融金属が疑固した 溶接金属の増加がみられ，メルトラン溶接の場合よりも豊 富な溶接金属を確保できた.第 5 図の写真だけではフィラー ワイヤを供給したビード溶接 (平板表面をメルトラン溶接) の溶融機構がわかりにくいので, ベース電流時とパルス電 流時に分けて模式的に第 6 图に示した .また , フィラーワ イヤ供給速度が遅い $\left(V_{\mathrm{W}}=26 \mathrm{~mm} / \mathrm{s}\right)$ 場合は, フィラー ワイヤがアーク柱内で溶融して塊となり, 溶融池へのフィ ラーワイヤ供給が不安定になる現象がみられた .

4.2 フィラーワイヤ供給速度がビード溶接の溶融特性に 及ぼす影響 フィラーワイヤを供給しながらメルトラン溶 接するビード溶接実験によって,フィラーワイヤ供給速度が ビード幅寸法に及ぼす影響を調査した . 第 7 図は光の結果 であるが , フィラーワイヤ供給速度はビード幅寸法にほと んど影響を及ぼさないことがわかる．ビード幅はアークの 拡がりすなわちアーク幅によってほぼ决定されるので，今 回のように電極高さ (アーク長) を $3 \mathrm{~mm}$ 一定値とした実 験ではアーク幅も一定値となる . 弚のために , フィラーワイ ヤ供給速度を変化させてもビード幅に変化が表れなかった 


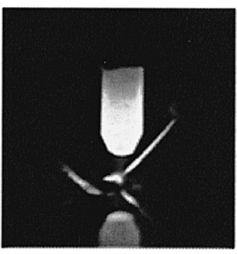

(1)

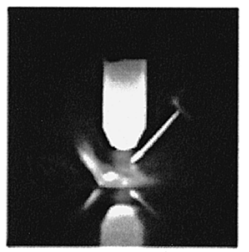

(2)

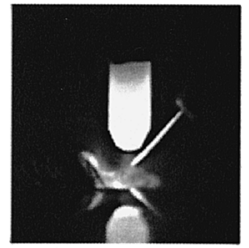

(3)

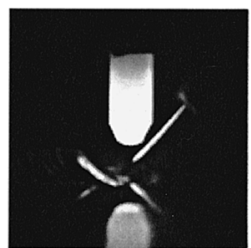

(4)

第 5 図 フィラーワイヤを供給した溶接の放電・溶融状況

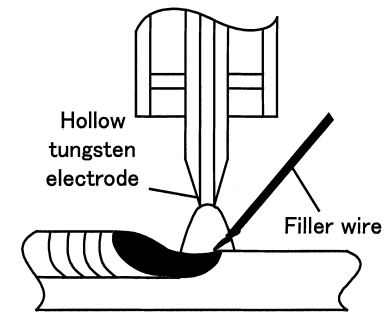

(a) ベース電流時

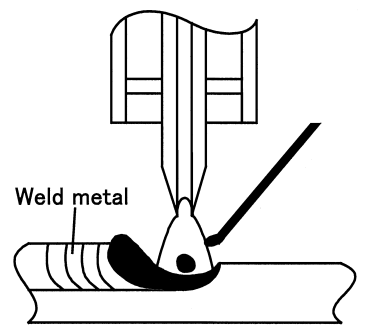

(b) パルス電流時

第 6 図 フィラーワイヤを供給したビード溶接における溶融機構

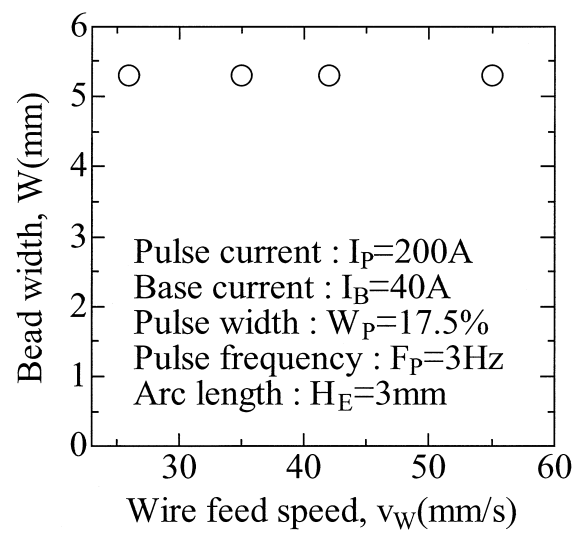

第7図 フィラーワイヤ供給速度がビード幅に及ぼす影響

と考えられる.第 8 図はフィラーワイヤ供給速度がビード 高さ (余盛高さ) に及ぼす影響である.フィラーワイヤ供給 速度を速くすると溶融金属量が増大するためにビード高さ が大きくなり，実験の範囲ではほぼ直線的に大きくなった 。 第 9 図はフィラーワイヤ供給速度を変化させたときの溶接 部のマクロ組織である. 第 9 図からフィラーワイヤ供給速 度の増加とともに溶接金属量か増加していることがわかる． ビード形成が良好な状態は，適度に速い速度でワイヤが供 給され, フィラーワイヤ先端の溶融金属が塊になる前の小

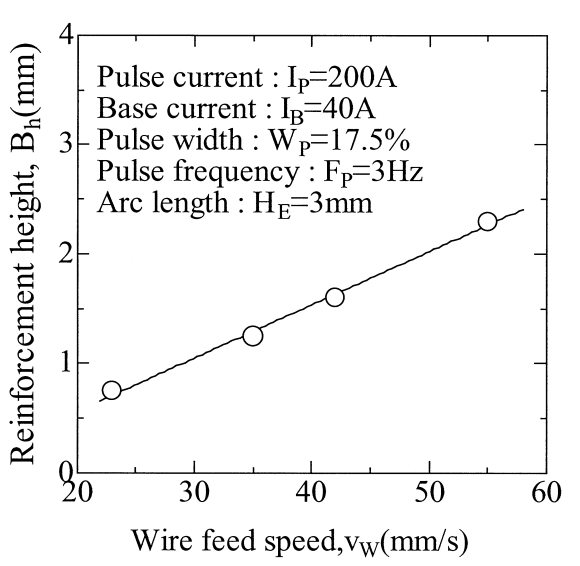

第 8 图 フィラーワイヤ供給速度がビード高さに及ぼす影響

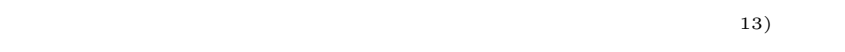
る. 供給速度 $V_{\mathrm{W}}=35 \mathrm{~mm} / \mathrm{s}$ の場合は, 光のようなビー ド形成がビデオ画像から確認できた．ワイヤ供給速度が大 きい場合には, 溶融池が盛り上がり電極先端と溶融金属が 短絡するほどになる . 溶融池表面の酸化膜か機械的に除去 される溶接条件でフィラーワイヤを供給しているので，母 材とフィラーワイヤの溶融金属は良好に融合し，第 9 図に 示すように融合不良などの溶接欠陥は見当たらない．これ らの結果より，真空中におけるアルミニウム合金の直流パ ルス GHTA 溶接では , フィラーワイヤを供給することに より溶接部のど厚を融合不良などの溶接欠陥を生じない状 態て増加させることが可能になった . 母材の板厚が $4 \mathrm{~mm}$ 程度であれば，ビード高さは一般的には $1.2 \mathrm{~mm}$ 程度か望 ましいとされているので, 第 8 図の図中に示された溶接条 件に対する最適フィラーワイヤ供給速度を $V_{\mathrm{W}}=35 \mathrm{~mm} / \mathrm{s}$ とした .

\section{3 突合せ溶接継手の製作と継手強度の評価}

4.3.1 突合せ溶接継手の製作 第 10 図に示す母材寸法 でI 型開先突合せ溶接継手を製作した .フィラーワイヤ 供給速度は, 前節で決定した最適フィラーワイヤ供給速度 $V_{\mathrm{W}}=35 \mathrm{~mm} / \mathrm{s}$ とし , ルートギャップの無い 1 パス 1 層の I 型開先突合せ溶接を行った . 突合せ溶接継手の表裏面の ビード外観を第 11 図 (a)，(b) に示した . 表面ビードには パルス電流によるリップルが観察される . 裏面のビードは 高さや幅には多少変動か認められるが, 1 パス 1 層溶接に よる完全溶込み溶接が可能なことがわかる . 

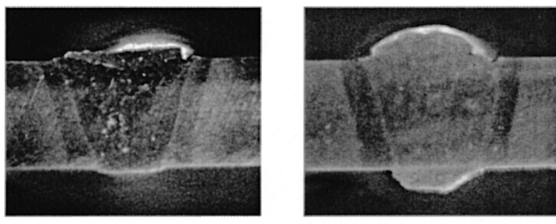

$v_{w}=26 \mathrm{~mm} / \mathrm{s}$

$v_{w}=35 \mathrm{~mm} / \mathrm{s}$

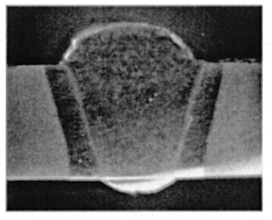

$v_{w}=42 \mathrm{~mm} / \mathrm{s}$

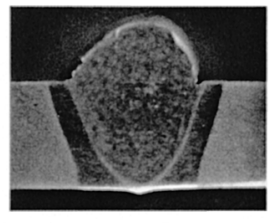

$v_{w}=55 \mathrm{~mm} / \mathrm{s}$

第 9 図 フィラーワイヤ供給速度を変化させたときのマクロ組織

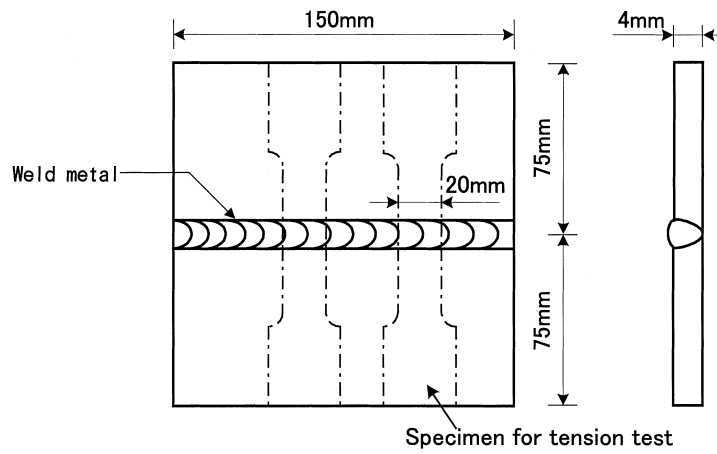

第 10 図＼cjkstart突合せ溶接継手と引張試験片

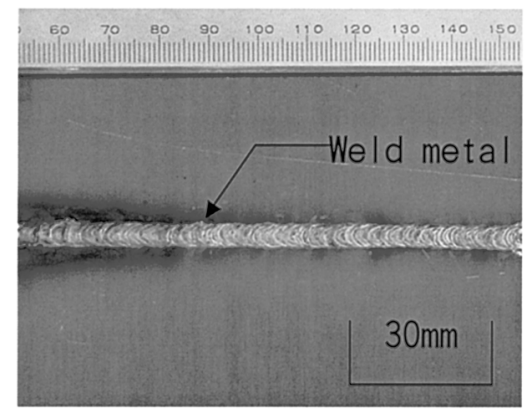

(a)Butt welding joint (Surface)

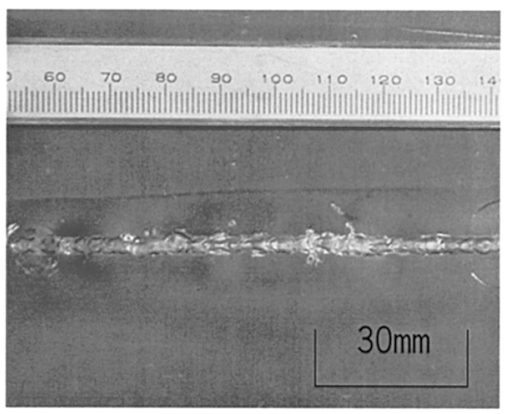

(b) Butt welding joint (Back)

第 11 図 突合せ溶接継手の外観

4.3.2 マクロ組織と硬度測定 フィラーワイヤを供給し ないメルトラン溶接による I 型開先突合せ溶接継手の製作 では, 溶接金属の不足によって溶接部のど厚が母材板厚よ りも小さくなる．㫕の結果，溶接金属部で破断するなど溶 接継手強度が低下する現象 ${ }^{14)}$ が発生した . 今回のフィラー ワイヤを供給する突合せ溶接継手の製作では, 第 12 図に 示したマクロ組織のように溶接部の表裏面におおむね良好

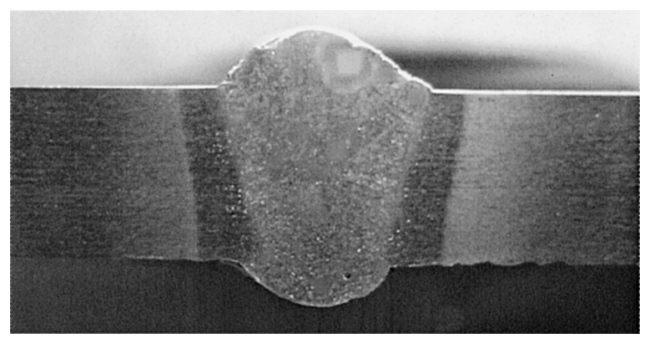

第 12 図 突合せ溶接継手のマクロ組織

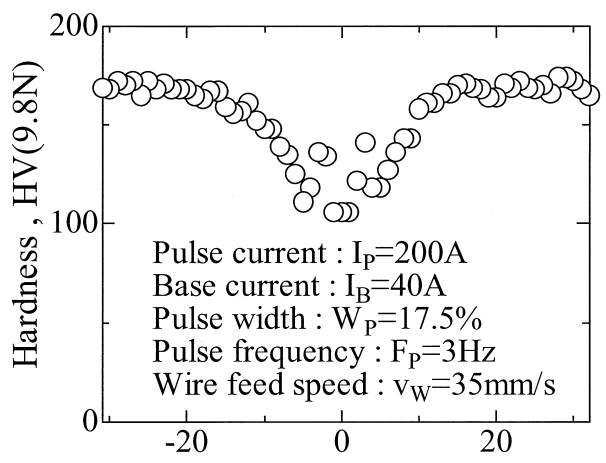

Distance from weld center, $\mathrm{x}(\mathrm{mm})$

第 13 図 突合せ溶接継手の硬度分布

な溶接金属を形成することができた . 第 13 図は母材表面 から $2 \mathrm{~mm}$ の位置で測定された硬度分布である . 溶接金属 部中心から両側約 $15 \mathrm{~mm}$ の範囲では, 溶接中の熱サイクル に原因する過時効による軟化が確認できる . 溶接金属中央 から約 $3 \mathrm{~mm}$ のボンド部付近では自然時効による硬度の回 復が認められる.一方，溶接金属部では硬度回復が確認で きないが , これはフィラーワイヤに含まれる $\mathrm{Cu}$ 成分が少 ないために自然時効が起きないためである .

4.3.3 突合せ溶接継手の引張試験 第 10 図に示した突 合せ溶接継手から図中に一点鎖線で示すように平行部幅 $20 \mathrm{~mm}$ の引張試験片を 11 本採取して引張試験を行った . 破断位置はボンド部すぐ外側の硬度が最も低い部分であっ た . 第 14 図は引張試験で得られた引張強さを正規確率紙 にプロットしたものである.引張強さの分布は正規確率紙 上で直線近似できることから正規分布で近似できることが わかる . 引張強さの平均値は $264.2 \mathrm{MPa}$ で, 過時効による 軟化によって母材強度の約 $55 \%$ になっている . 変動係数は $18.2 \%$ で, 多少大きな值になっている . 2000 系アルミニウ ム合金の溶接の場合，過時効による強度低下が避けられな 


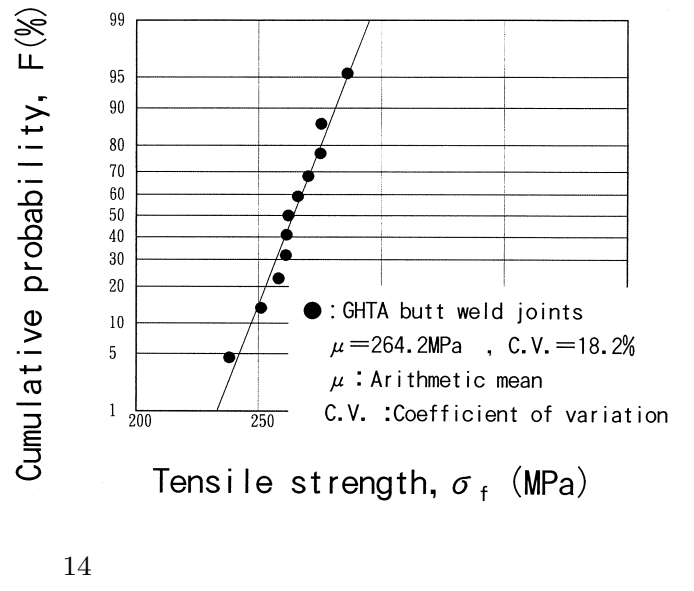

いことや同じ供試材を大気中での溶接作業に適用される通 常の交流 GTA 溶接で製作した溶接継手強度か滋 $260 \mathrm{MPa}$ で, 少の值とほぼ同じであることを考慮するとほぼ満足で きる溶接継手強度と言える．これらの結果から，直流パル ス電源を使用してフィラーワイヤを供給する宇宙 GHTA 溶 接法が , 宇宙環境でのアルミニウム合金の溶接作業に適用 できる可能性を示した .

\section{5. 結論}

小型ワイヤ供給装置を使用したアルミニウム合金の宇宙 GHTA 溶接実験を行い, 以下のことを明らかにした 。

1) フィラーワイヤを供給するメルトラン溶接の母材の溶 融機構は基本的にフィラーワイヤを供給しないメルトラン 溶接とほぼ同じであった .

2) フィラーワイヤの溶融状況と供給速度がビード寸法・ 形状に及ぼす影響を明らかにした .

3) フィラーワイヤを供給する直流パルス GHTA 溶接で は溶融池表面の酸化膜力除去されるために, 母材とフィラー ワイヤの溶融金属は欠陥を発生することなく融合すること を示した 。

4) フィラーワイヤを供給する直流パルス GHTA 溶接に よって , 板厚 $4 \mathrm{~mm}$ のアルミニウム合金を 1 パス 1 層の I 型開先突合せ溶接継手を欠陥無く製作できる.

5) 最適フィラーワイヤ供給速度により直流パルス GHTA 溶接で製作した継手強度は大気中の GTA 溶接による継手
強度とほぼ同等であった。

6) 真空環境でフィラーワイヤを供給してアルミニウム合 金を溶接する要素技術を確立した .

本研究の一部は, 科学研究費補助金 (15560634) の助成 により遂行された．また，本研究に対して長期間にわたつ て御支援をいただいている財団法人南海育英会に心から御 礼を申し上げる。

\section{参 考 文 献}

1) 日本機械学会宇宙工学部門第 81 期運営委員会編集 : 日本機械学 会会員のための宇宙工学概論，2004, pp. 145-154.

2) Paton, B. E.: Welding in Space, Welding Engineer, 57 (1972), pp. 25-29.

3) Schollhammer, F. R.: Electron Beam Welder for Space, National Symposium Materials for Space Vehicle Use, 6th Soc. Aerospace Material and Process Eng., Seattle, Wash., 1963, p. 51.

4) Kaukler, W. F. and Workman, G. L.: Laser Welding in Space, Proceedings from the Conference "Welding in Space and the Construction of Space Vehicles by Welding," New Carrollton, Maryland, USA, 1991, pp. 318-334.

5) Newton-Montiel, B.: Workshop Launches Welding in Space Research, Welding J., 69, 3 (1990), pp. 45-47.

6) Johnsen, R.: Space Welding Experiment Postponed Indefinitely, Welding J., 76, 4 (1997), p. 22.

7) 宇宙での溶接 OK (読売新聞，13 版全国版)，「宇宙空間」での溶 接実験に成功（朝日新聞，13 版全国版），平成 4 年 5 月 29 日付。

8）吹田義一, 佃 芳行, 高木 隆, 黄地尚義, 増郑興一: 宇宙空間 での GTA 溶接に関する研究 (第 1 報)，溶接学会論文集，11 (1993), pp. 423-427.

9) 吹田義一,増郑興一,佃 芳行, 寺嶋 昇, 小笠原正信, 高橋 永: 宇宙空間での宇宙船・構造物の建造と修理を対象にしたアーク溶接 法の開発，日本機械学会論文集 C 編 , 61 (1995), pp. 2134-2140.

10）吹田義一, 佃芳行, 寺嶋昇, 八田崇, 河野鉄平, 猪熊力也, 川田賢司, 黄地尚義, 西川宏, 吉田和弘, 増㴊興一: 航空機を 使用した模擬宇宙環境下での GHTA 溶接実験，溶接学会論文集， 18 (2000), pp. 228-235.

11) 吹田義一, 高井大輔, 杉山智志, 寺嶋 昇, 佃 芳行, 藤澤正一 郎，今川吉郎：ISS 軌道圧力でのアルミニウム合金の宇宙 GHTA 溶接実験，日本航空宇宙学会論文集，52 (2004), pp. 10-15.

12）吹田義一, 永井宏和, 新池修平, 佃 芳行, 寺島 昇, 藤澤正一 郎 , 増郑興一, 今川吉郎, 山下雅弘 : アルミニウム合金の真空中で の GHTA 溶接現象, 溶接学会論文集, 22 (2004), pp. 521-526.

13) 本間信吾, 安田克彦 : 半自動 TIG 溶接に関する研究, 溶接学会 論文集，21 (2003), pp. 356-361.

14）吹田義一, 佃 芳行, 寺島 昇, 高橋 永, 小笠原正信, 黄地尚 義, 増㴊興一 : 真空中での GHTA 溶接によるアルミニウム合金 の溶接 , 溶接学会論文集 , 14 (1996), pp. 634-640. 